\title{
PEMBERDAYAAN MASYARAKAT DALAM MENGIMPLEMENTASIKAN NILAI PANCASILA UNTUK MENGHADAPI GLOBALISASI DAN ERA INDUSTRI 4.0
}

\author{
Wicipto Setiadi ${ }^{1}$, Iwan Joesoef Erar ${ }^{2}$, Muhammad Helmi Fahrozi ${ }^{3}$ \\ 1, 2,3 Fakultas Hukum Universitas Pembangunan Nasional Veteran Jakarta \\ Email: wiciptosetiadi@upnvj.ac.id
}

\begin{abstract}
Abstrak
Dampak Tekhnologi sangat cepat, prinsipnya bisa menjadi ancaman bagi warga negara Indonesia, khususnya pada beberapa seperti daerah-daerah penompang ibukota. Hal ini harus diantisipasi mulai dari pemuda/I nya, untuk menangkal tergerusnya nilai-nilai pancasila yang sudah tidak lagi di sosialisasikan secara massif oleh pemerintah. Oleh karena itu, kegiatan pengabdian masyarakat sosialisasi nilai pancasila menjadi penting bagi akademisi hukum agar setiap warga negara tetap mengedepankan nilai-nilai Pancasila dalam kehidupan seharihari. Pemberdayaan masyarakat dan Sosialisasi dilaksanakan di Kota Bekasi, sebagai daerah penompang ibu Kota yang menjadi sasaran industrialisasi perkembangan tekhnologi, maka kebutuhan agar manghadapi ancaman penurunan pemahaman ideologi negara dan dasar negara menjadi tepat untuk dilakukan di Kota Bekasi, Tim Pengabdian Masyarakat membentuk komunitas dan beberapa program yang berkelanjutan agar dalam kehidupan berbangsa dan bernegara di Kota Bekasi Khususnya pada Kecamatan Bekasi Utara Kelurahan Bahagia warga Komlek Bahagia dan Komplek Barokah RT 07 RW 07, dapat memahami dan melanjutkan pemahaman nilai-nilai Pancasila sebagai ideoologi negara dan dasar negara.
\end{abstract}

Kata Kunci: Nilai-Nilai Pancasila, Pemberdayaan Masyarakat, Globalisasi, Industri 4.0

\begin{abstract}
The impact of technology is very fast, in principle it can be a threat to Indonesian citizens, especially in some areas such as the capital lifting regions. This should be anticipated starting from the youth / I, to prevent the erosion of the values of Pancasila, which is no longer disseminated on a massive scale by the government. Therefore, community service activities to promote the values of Pancasila become important for legal academics so that every citizen continues to prioritize the values of Pancasila in their daily lives. Community Empowerment and Outreach is carried out in Bekasi City, as a capital for the capital city which is the target of industrialization for technological development, so the need to face the threat of decreasing the understanding of state ideology and the state foundation becomes appropriate to be carried out in Bekasi City, the Community Service Team forms a community and several programs that sustainable so that in the life of the nation and state in the city of Bekasi, especially in North Bekasi Sub-district, Bahagia Sub-district, residents of the Bahagia Komlek and Barokah Complex RT 07 RW 07, can understand and continue to understand the values of Pancasila as the ideology of the state and the basis of the state.
\end{abstract}

Keywords: Pancasila Values, Community Empowerment, Globalization, Industry 4.0. 


\section{A. PENDAHULUAN}

Nilai-nilai yang terkandung dalam Pancasila akan mengajarkan kepada masyarakat untuk bertindak dan berprilaku sesuai dengan ideologi bangsa dan indeologi negara Indonesia tidak hanya untuk masyarakat umum namun untuk masyarakat yang berpendidikan agar lebih memiliki karakter pancasilais perkembangan globalisasi termasuk kemajuan tekhnologi banyak mendirupsi berbagai aspek dalam kehidupan bermasyarakat, pengaruh negatif bermunculan ditengah-tengah masyarakat akibat perkembangan tekhnologi serta menjamurnya idnustri 4.0, hal ini sedikit banyak melunturkan nilai nilai luhur yang sudah di bangun oleh para pendiri bangsa. tidak menutup kemungkinan permasalahan yang muncul kemudian adalah warga negara Indonesia yang lupa akan jati diri bangsanya sendiri.

Atas dasar tanggung jawab sebagai akademisi, khusunya sebagai akdemisi di bidang hukum yang memahami bahwa ideologi adalah peletak dasar utama norma hukum (grundnorm), artinya membumikan nilai-nilai Pancasila sebagai pemberdayaan masyarakat, adalah suatu hal keharusan yang di lakukan oleh para Tenaga Pendidik (Dosen), Pelaksanaan pemberdayaan yang dipilih oleh tim pengabdian masyarakat kepada kecamatan Bekasi Utara, Kota Bekasi menjadi dasar utama untuk mengawal permasalahan tersebut tidak terjadi kepada wilayah yang di sematkan sebagai salah satu wilayah "Penopang Ibu Kota".

Bekasi merupakan wilayah sub urban, dan merupakan kota satelit penopang sebuah kota besar yaitu Jakarta. Bekasi yang berkembang bukan hanya menjadi tempat tinggal kaum urban namun juga berkembang menjadi sebuah kota industri barang dan jasa. Daerah yang dahulunya merupakan wilayah agraris kemudian bertransformasi menjadi kota yang di dominasi oleh kegiatan perindustrian. Arus modernisasi terus merambat terlihat dari banyaknya pusat-pusat perbelanjaan dan pusat-pusat industri membuat Kota Bekasi terus bertransformasi menjadi sebuah kota yang modern.

Banyak dari kota-kota di Indonesia terus bergerak menuju sebuah identitas baru dan meninggalkan identitas lamanya. Perubahan yang terjadi banyak dimulai di abad 20 ketika kosmopolitanisme bergulir. Benda-benda yang menjadi simbol modernitas telah menjadi orientasi baru pada masyarakat perkotaan, terlihat di dalam pembangunan infrastruktur dan fisik kota yang kemudian menyesuaikan dengan gaya kosmopolit.

Periihal yang tentu saja permasalahan tersebut terjadi pada wilayah kota bekasi, memperparah kondisi fakta bahwa kota di berbagai kecamatan di dalamnya harus menanggung konsekuensi perubahan sosial, budaya, ekonomi dan tekanan terhadap lingkungan di Kota Bekasi pada umumnya. 
Membumikan Pancasila bisa dimulai dari hal-hal kecil dan sederhana, seperti dengan memakai pakaian adat, alat musik, menimkmati makanan daerah hingga yang paling utama menghargai dan menghormati perbedaan. Dewasa ini, banyak tantangan yang di hadapi oleh ideologi bangsa dan ideologi negara untuk dapat di terapkan kepada masyarakat, terlebih dengan berkembangnya tekhnologi dan ilmu pengetahun yang di dasari oleh perkembangan industri terkini Industri 4.0. sudah sepantasnya apabila warga negara Indonesia pada umumnya perlu meng"counter"kan dirinya terhadap perubahan perubahan saat ini, khusunya waraga negara Kecamatan Bekasi Utara di Kota bekasi yang menjadi salah satu terkena dampak efek kosmopolitannya wialyah tempat urabnisasi asyarakat dari desa ke kota.

Khusunya pula kepada generasi milenial yang tidak dapat dihindarkan oleh perkembangan tekhnologi seperti sosial media. Tantangan milenial adalah prinsipnya masalah dari sosial media, Melalui sosial media kita bisa mengambil manfaat tapi juga bisa merusak bangsa kita sendiri. Jangan sampai kita berita hoax yang tersebar melalui sosial media dapat menyudutkan satu kelompok tertentu dengan menyuarakan ujaran kebencian.

Adanya pemerataan ekonomi di wilayah Jakarta menjadikan Bekasi menjadi salah satu kawasan kegiatan berbagai Industri dan pembangunan pemukiman. Mulai terjadi banyak pengalihan lahan, yang tadinya merupakan lahan persawahan dan perkebunan menjadi wilayah Industri dan juga pemukiman. Urbanisasi besar-besaran pun tak terhindarkan, daerah bekasi yang dahulunya adalah pedesaan dengan basis kegiatan di sektor pertanian lalu beranjak menjadi perkotaan dengan aktivitas kegiatan industri yang tak ada kaitannya dengan pertanian. Bekasi merupakan daerah yang subur, banyaknya lahan yang ada dipergunakan sebagai lahan pertanian mulai bergeser penggunannya. Secara geo-ekonomi posisi bekasi sangatlah strategis dekat dengan pusat ibu kota Jakarta. Selain itu juga fasilitas penyangga lainnya seperti jalan kereta api, pusat jalan raya dan letak wilayah yg strategis bagi jalur ekonomi membuat Bekasi menjadi salah satu wilayah yang banyak diminati para investor.

Undang-Undang tentang pembentukan Perumnas melalui Keppres RI No.29/1974 juga berpengaruh dalam perkembangan Kota Bekasi dan juga bertambah pesatnya penduduk luar yang datang ke Bekasi. Gagasan tersebut merupakan salah satu upaya untuk pemekaran kota dan perbaikan kampung. Dalam menjalankan programnya pemekaran dilakukan terhadap kota-kota yang berada dekat dengan Jakarta secara geografis. Hal ini kemudian yang membuat banyak masuknya eksodus para pendatang.

Wilayah kota Bekasi pada awalnya merupakan kota kecil tipikal Indonesia. Akibat dari pembangunan dampak dari masuknya industrialisasi dan arus urbanisasi yang sangat 
pesat, mengakibatkan lonjakan penduduk yang cukup besar. Atas dasar itu sebagian wilayah yang termasuk dalam kawasan berkembang utamanya di wilayah Kecamatan Bekasi pada tahun 1981 melalui PP no. 48/1981 telah ditetapkan sebagai Kotif (Kota Administratif). Proses terbentuknya Kota Bekasi tidak serta merta terjadi begitu saja. Tidak seperti kota Jakarta yang sejak dahulu dirancang sebagai sebuah kota, Bekasi tumbuh dan berkembang mengikuti perkembangan yang terjadi di sekitarnya. Dalam hal ini yang sangat berpengaruh terhadap perkembangan Kota Bekasi adalah jarak yang dekat dan berbatasan langsung dengan Jakarta. Arus modernisasi dan urbanisasi dalam skala yang besar terjadi kemudian mengakibatkan banyaknya terjadi perubahan.

Hal ini terlihat dari perubahan dari desa menjadi sebuah kota. Menurut perspektif evolusioner, perkembangan suatu kota selalu dikaitkan dengan pedesaan. Paradigma modernisasi kemudian akan membawa sebuah perubahan bahwa setiap desa kemudian akan berkembang menjadi kota, dan kota akan berkembang melewati tahapan-tahapan perkembangan tertentu. Selain itu juga setiap kota merupakan hasil perkembangan dari suatu desa. Tahap-tahap perkembangan itu bersifat linear dan universal. Setidaknya ada 3 faktor yang mempengaruhi di dalam pembentukan Bekasi sebagai sebuah kota modern.

Pertama adalah adanya penerapan Konsepsi Jabotabek yang menyebabkan Bekasi harus dapat menerima limpahan penduduk dari Jakarta, selain itu juga Bekasi sebagai kota satelit/kota penopang harus dapat menyesuaikan perkembangannya dengan kota Induk. Kebijakan mengenai pemekaran wilayah Jakarta melalui kebijakan JABOTABEK yang kemudian mengakibatkan daerahdaerah disekitarnya menjadi wilayah penampung.

Kedua dengan dijadikannya Bekasi sebagai pusat perindustrian, turut serta membuat banyak perubahan yang ada disana. Proses perubahan tersebut membawa konsekuensi terjadinya perubahan di berbagai sektor kehidupan dan tata ruang kota di Bekasi.

Ketiga, keputusan yang menjadikan Bekasi menjadi sebuah wilayah Industrialisasi menandai pula transisi Bekasi ke arah modernisasi. Ditambah lagi dengan diangkat status administrasi kecamatan Bekasi menjadi Kotif (Kota administratif) pada tahun 1982. Sehingga transisi Bekasi menjadi sebuah Kota sangat lebih terasa lagi mulai dari pertumbuhan ekonomi, peningkatan fasilitas publik sarana prasarana penunjang kota dan pertumbuhan penduduk yang juga semakin pesat. 


\section{B. METODE DAN PELAKSANAAN}

Pemberdayaan masyarakat adalah upaya untuk memberikan daya (empowerment) atau penguatan (strengthening) kepada masyarakat. Pemberdayaan masyarakat juga diartikan sebagai kemampuan individu yang bersenyawa dengan masyarakat dalam membangun keberdayaan masyarakat yang bersangkutan sehingga memiliki tujuan agar mendapatkan kreasi dan pandangan baru dalam mengatasi permasalahan yang terdapat $\mathrm{d}$ masyarakat.

Sedikitnya terdapat enam karakter atau ciri-ciri dari pemberdayaan masyarakat, yakni : Pertama, untuk merevitalisasi kelompok sosial yang terdapat dalam masyarakat menjadi lebih baik lagi (Better Organization/Institution). Dengan adanya perombakan secara struktur maupun fungsionalis secara kelembagaan atau organisasi di harapkan kemudian hari setelah pemberdayaan masyarakat dilaksanakan, maka akan terjadi perkembangan yang signifikan terhadap perilaku warga negara terhadap hal-hal yang lebih positif dari pada sebelumnya.

Kedua, Perbaikan usaha (Better Enterpreunurship). Dengan adanya pembaharuan secara pendidikan, semangat belajar yang terus di "gaung" kan secara berulang-ulang, serta aksessosialitas menjadi lebih mudah terhadap setiap warga negara kepa pemerintah, diharapkan adanya perbaikan usaha dan kegiatan yang di lakukan warga masyarakat dalam kehidupan bernagsa dan benegara.

Ketiga, perbaikan pemahaman dan pendapatan, pendapatan yang di terima oleh masyarakat memungkinkan memberikan efek pengaruh terhdapa pemahaman yang diterima oleh masyarakat, Keempat merevitalisasi lingkungan (Better Enviroment). Dengan adanya perbaikan lingkungan diharapkan baik secara fisik maupun sosial di masyarakat tidak mengalami kerusakan kembali pasca pemberdayaan masyarakat di laksanakan.

Kelima, Perbaikan Kehidupan (Better Living) tingkat keinginsejahteraan masyarakat dalam kehidupan sehari-hari tidak hanya dari aspek ekonomi namun dapat di perbaiki dari aspek kemanan, dan kenyamanan berkehidupan sosial di tengah masyakarat. Pendapat lain tentang pemberdayaan masyarakat juga di ungkapakna oleh berbagai macam ahli salah satunya adalah Menurut Fahrudin. pemberdayaan masyarakat adalah upaya untuk memampukan dan memandirikan masyarakat yang dilakukan dengan upaya sebagai berikut: 


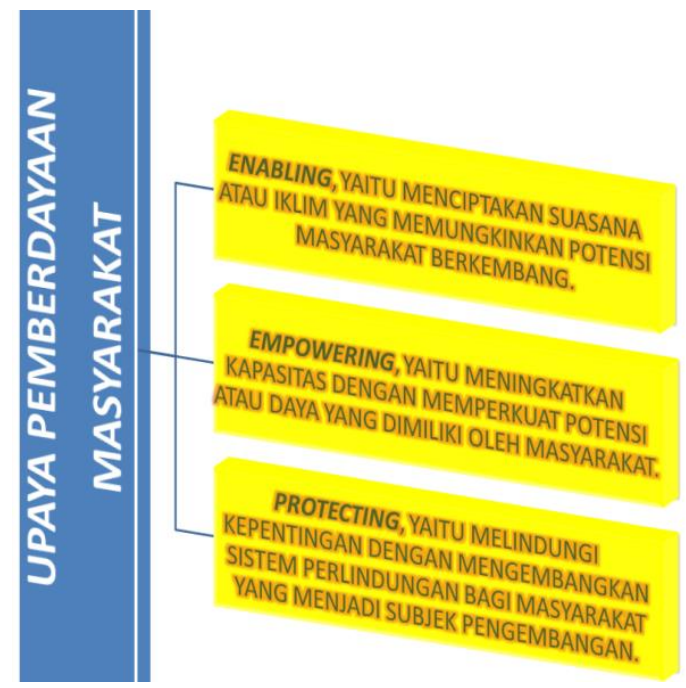

\section{Gambar 1 Enabling, Empowering dan Protecting}

Mengukur titik tolaknya Enabling adalah pengenalan bahwa setiap manusia, setiap masyarakat memiliki potensi yang dapat dikembangkan. Pemberdayaan adalah upaya untuk membangun daya itu dengan cara mendorong (encourage), memotivasi dan membangkitkan kesadaran (awareness) akan potensi yang dimilikinya serta berupaya untuk mengembangkannya. Selain itu, dalam pelaksanaan Empowering Perkuatan ini meliputi langkah-langkah nyata seperti penyediaan berbagai masukan (input) serta pembukaan akses kepada berbagai peluang yang dapat membuat masyarakat menjadi makin berdayaan, adapun mengenai Protecting, Dalam proses pemberdayaan harus dicegah yang lemah menjadi bertambah lemah, oleh karena kekurangberdayaan dalam menghadapi yang kuat. Melindungi dalam hal ini dilihat sebagai upaya untuk mencegah terjadinya persaingan yang tidak seimbang serta eksploitasi yang kuat atas yang lemah.

Tujuan utama pemberdayaaan adalah memperkuat kekuasaaan masyarakat. khususnya kelompok lemah yang memiliki ketidakberdayaan, baik karena kondisi internal (misalnya presepsi mereka sendiri), maupun karena kondisi eksternal (misalnya ditindas oleh struktur sosial yang tidak adil). Ada beberapa kelompok yang dapat dikategorikan sebagai kelompok lemah atau tidak berdaya meliputi: Kelompok lemah secara stuktural, naik lemah secara kelas, gender, maupun etnis. Kelompok lemah khusus, seperti manula, anak-anak, dan remaja penyandang cacat, gay dan lesbian, masyarakat terasing. Hingga Kelompok lemah secara personal, yakni mereka yang mengalami masalah pribadi atau keluarga.

Pengembangan nilai-nilai Pancasila sekarang ini kian hari kian terkikis, hal ini dibuktikan dalam bentuk pengetahuan, sikap, maupun perilaku yang terjadi dalam kehidupan 
sehari-hari yang dilakukan oleh bangsa ini. Tindakan-tindakan yang seharusnya tidak dilakukan justru dimunculkan sehingga memicu terjadinya berbagai perselisihan, permusuhan maupun perpecahan. Pancasila sebagai dasar negara dan ideologi nasional memiliki makna yang sangat jelas bagi bangsa Indonesia. Pancasila sebagai dasar Negara setidaknya perlu dipahami bahwa nilai-nilai yang terkandung dalam Pancasila merupakan dasar ataupun pondasi bagi bangsa ini dalam segala penyelenggaraan ketatanegaraan. Pancasila sebagai dasar pembentukan norma hukum dan norma etik bagi bangsa Indonesia ini. Pancasila sebagai ideologi nasional mengandung makna bahwa nilai-nilai Pancasila itu sebagai cita-cita bangsa Indonesia dan alatpemersatu bagi bangsa ini. Selain kedudukan pokok Pancasila sebagai dasar negara, Pancasila juga memiliki kedudukan lain, yaitu Pancasila sebagai Jiwa Bangsa Indonesia. Pancasila sebagai Kepribadian Bangsa Indonesia. Pancasila sebagai Pandangan Hidup Bangsa Indonesia. Pancasila sebagai Sumber Dari Segala Sumber Hukum atau Sumber Tertib Hukum Negara Republik Indonesia. Pancasila sebagai Perjanjian Luhur Bangsa Indonesia pada waktu mendirikan negara.

Implementasi nilai-nilai pancasila yang di terapkan pada masyarakat RT 07 Bulak Perwira II Kelurahan Perwira Kecamatan Bekasi Utara Kota Bekasi, akan lebih lengkap di ketahui setelah pengolahan data yang di lakukan oleh tim pengabdi. Kebutuhan akan penerapan nilai pancasila oleh masyarakat setempat pada prinsipnya sangat antusias menerima kehadian tim pengabdi.
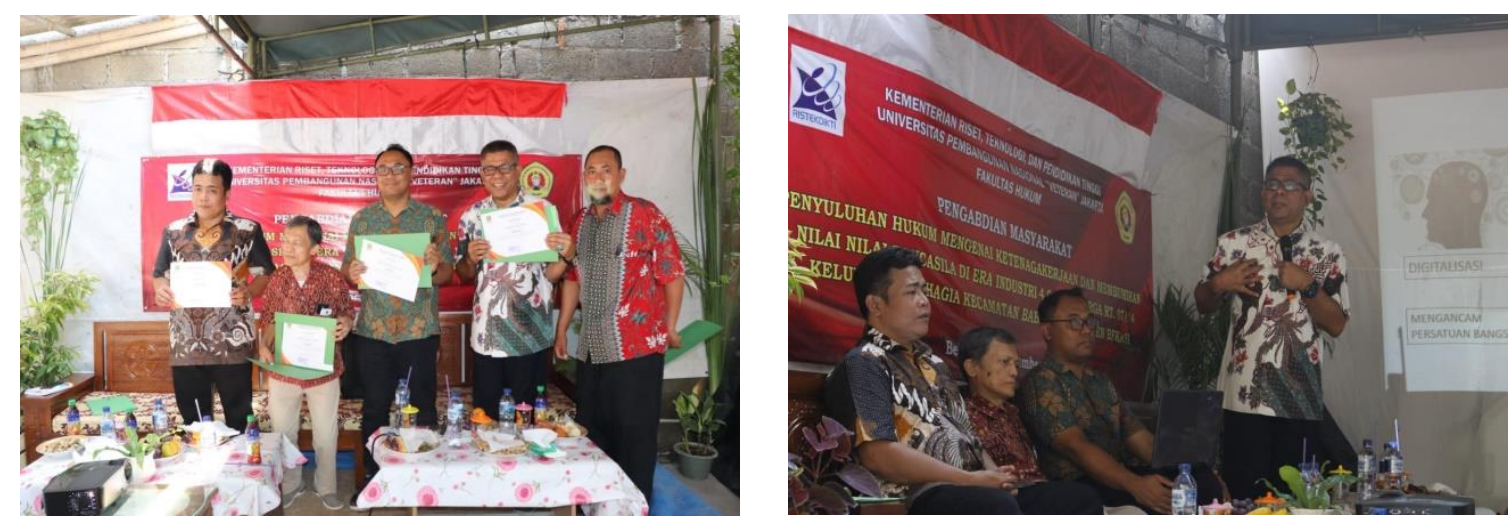

\section{Gambar 2 Presentasi Sosialisasi Nilai Pancasila}

Sosialisasi adalah suatu proses belajar-mengajar atau penanaman nilai, kebiasaan, dan aturan dalam bertingkah laku di masyarakat dari satu generasi ke generasi lainnya sesuai dengan peran dan status sosial masing-masing di dalam kelompok masyarakat, Melalui proses sosialisasi maka seseorang dapat memahami dan menjalankan hak dan kewajibannya berdasarkan peran status masing-masing sesuai budaya masyarakat. Dengan kata lain, 
individu mempelajari dan mengembangkan pola-pola perilaku sosial dalam proses pendewasaan diri. Sosialisasi diperoleh melalui kontak dengan lingkungan sosialnya, kontak dengan orang lain di masyarakat. Sosialisasi berkembang dari lingkup kecil keluarga yang semakin lama semakin meluas. Sosialisasi mempunyai arti dalam pembinaan kepribadian agar seseorang dapat hidup konform dengan tuntutan kelompok dan kebudayaannya. Sosialisasi diarahkan bagi kelangsungan masyarakat, kelompok sosial dan kebudayaan.

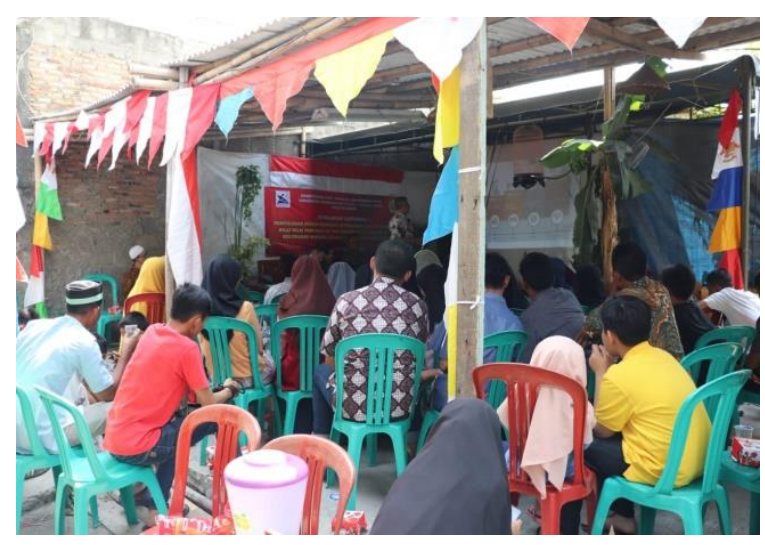

\section{Gambar 3 Penerimaan Tanda Apresiasi Warga}

\section{HASIL DAN PEMBAHASAN}

Pasca kegiatan pengabdian masyarakat yang di laksanakna berdasarkan konsep pemberdayaan masyarakat serta sosialisasi. Maka, hasil yang dicapai dari pelaksanaan kegiatan pengabdian masyarakat ini adalah peningkatan pengetahuan masyarakat terkait implementasi nilai-nilai pancasila dalam kehidupan bermasyarakat sehari-hari semiakin meningkat, para peserta yang hadir dapat mengetahui bagaimana urgensi jati diri bangsa untuk mempertahankan rasa nasionalisme seseorang sebagai warga negara yang baik.

Permasalahan negara saat ini sudah banyak muncul dari ketidak tahuan dan ketidakingin-tahuan warga negara Indonesia tentang Nilai-nilai Pancasila. Misal, seperti banyaknya warga negara Indonesia sudah mulai terapapar ideologi dan paham lain, selain ideologi atau paham negara Indonesia yang telah disepakati para Founding Father negara Kesatuan Republik Indonesia yaitu Pancasila.

Satu hal yang paling terlihat adalah pencabutan izin organisasi yang sudah lama berdiri namun memiliki ideologi yang berbeda ketika dilihat dari program dan kegiatan organisasi tersebut. Hal ini tegas membuktikan bahwa warga negara Indonesia bisa saja masuk kedalam pemikiran yang tidak sejalan dan tidak sesuai dengan ideologi negara serta 
ideologi bangsa. Terlebih lagi di dukung dengan berkembangnya tekhnologi karena arus globalisasi yang tidak dapat di bendung dengan regulasi pemerintah saja.

Dengan semakin banyaknya penggunaan teknologi dalam kehidupan, salah satu yang patut diwaspadai adalah penggunaan teknologi yang tidak bertanggung jawab yang dapat berdampak pada rusaknya persatuan dan kesatuan bangsa. Sudah banyak peristiwa yang mengarah ke sana, sebagai contoh: penggunaan media sosial (medsos) untuk menyebarkan ajaran-ajaran radikal yang berpotensi melukai Kebhineka Tunggal Ika-an bangsa, mudahnya seseorang memberikan ujaran kebencian kepada orang lain melalui media sosial, serta tindakan-tindakan ekstrem seperti bom bunuh diri di beberapa tempat ibadah. Bahkan aktivitas ini seakan semakin tidak terkendali karena begitu mudahnya membuat akun media sosial serta semakin banyaknya masyarakat bangsa ini yang mudah terpancing dengan isu-isu radikal tersebut.

Pemerintah memang tidak tinggal diam dalam menyikapi beberapa peristiwa tersebut. Tetapi yang menjadi masalah adalah dunia teknologi adalah dunia yang cair dan dinamis. Ketika pemerintah sudah berusaha untuk memblokir beberapa akun media sosial yang meresahkan, maka bisa dipastikan akan semakin banyak muncul akun-akun baru yang serupa. Pancasila merupakan pemersatu bangsa. Dari sini kita bisa melihat bahwa semua tindakan yang membahayakan persatuan dan kesatuan bangsa, termasuk juga yang dilakukan dengan perantaraan teknologi berarti telah melukai Pancasila. Kelima sila dalam dasar Negara kita bukanlah hanya untaian kalimat-kalimat kosong yang hanya akan menghiasi buku-buku pelajaran. Lambang Burung Garuda Pancasila bukan pula hanya sekadar pajangan yang wajib menghiasi dinding setiap rumah.

Justru yang harus kita sadari adalah bahwa dengan adanya Pancasila maka seluruh elemen bangsa yang sangat beragam, akan dapat disatukan termasuk ketika kita semakin akrab dalam menggunakan teknologi pada kehidupan kita. Semakin tinggi penggunaan teknologi, seharusnya kita semakin bersatu dengan orang lain karena pada dasarnya teknologi diciptakan untuk membuat hidup kita menjadi lebih baik. Negara kita memiliki lima sila. Lima merepresentasikan bilangan ganjil. Sesuatu yang masuk dalam kategori bilangan ganjl, akan menjadi lebih lengkap jika ada bilangan genap. Maka, kelima sila dalam Pancasila tersebut akan menjadi semakin lengkap jika kita mampu menggenapinya dengan berperilaku sesuai dengan pesan-pesan yang tersirat dari sila-sila tersebut.

Dengan upaya pemberdayaan masyarakat sebagaimana dipaparkan di atas, diharapkan masyarakat dapat lebih menyadari bahwa mereka memiliki sumberdaya yang kuat dalam 
menata dan membangun kesejehtaraannya sendiri. Dengan upaya pemberdayaan ini pula masyarakat dapat lebih menyadari betapa pentingnya memiliki adat budaya yang relevan dengan prinsi dan nilai-nilai Pancasila sebagai ideology bangsa. Faktor kualitas nilai yang terkandung dalam Pancasila tidak perlu diragukan, tetapi faktor pemahaman dan sikap masyarakat, faktor kemampuan masyarakat, dan faktor pembudayaan dan pengamalan ideologi masih memerlukan usaha untuk dapat mempertahankan, memantapkan, memapankan, dan mengokohkan Pancasila. Untuk itulah perlu adanya usaha secara serius, dengan jalan mengimplementasikannya dalam segala aspek kehidupan masyarakat berbangsa dan bernegara.

Pancasila memiliki potensi menampung keadaan pluralistik yang dialami oleh bangsa Indonesia, ditinjau dari keanekaragaman agama, suku bangsa, adat budaya, ras, golongan dan sebagainya. Sila pertama Ketuhanan Yang Maha Esa, menjamin kebebasan bagi warganegara untuk beribadah sesuai dengan agama dan keyakinannya. Sementara itu Sila ketiga persatuan Indonesia, mengikat keanekaragaman tersebut di atas dalam suatu kesatuan bangsa dengan tetap menghormati sifat masing-masing seperti apa adanya.

Salah satu faham yang mendasari pelaksanaan demokrasi adalah faham pluralisme. Pluralisme berasal dari kata Latin plural yang berarti majemuk, yang bermakna bahwa setiap entitas diakui seperti apa adanya, dan keberadaan setiap entitas tidak perlu digantikan oleh entitas yang lain. Pluralisme mengakui adanya perbedaan individu. Perbedaan yang terdapat dalam setiap individu merupakan suatu hal yang hakiki serta diakui dan dihormati. Eksistensi setiap individu diakui seperti apa adanya.

Pluralisme menolak totaliterisme, suatu faham yang ingin mensubstitusi keaneka ragaman menjadi satu entitas saja. Kehidupan masyarakat dalam berbangsa dan bernegara memerlukan konsensus, tanpa konsensus tidak akan terjadi gerak bersama. Oleh karena itu dalam masyarakat yang menganut faham pluralisme, warganya dituntut bersikap toleran agar dapat tercipta kesepakatan. Tanpa toleransi yang terjadi hanya pertentangan yang tiada berkesudahan, manusia memandang manusia yang lain laksana serigala dan perang semua melawan semua (homo homini lupus dan bellum omnium contra omnes).

Pancasila memberikan jaminan terealisasinya kehidupan yang pluralistik, dengan menjunjung tinggi dan menghargai manusia sesuai dengan harkat dan martabatnya sebagai makhluk Tuhan secara berkeadilan, disesuaikan dengan kemampuan dan hasil usahanya. Hal ini ditunjukkan oleh sila kedua yaitu Kemanusiaan yang adil dan beradab. 

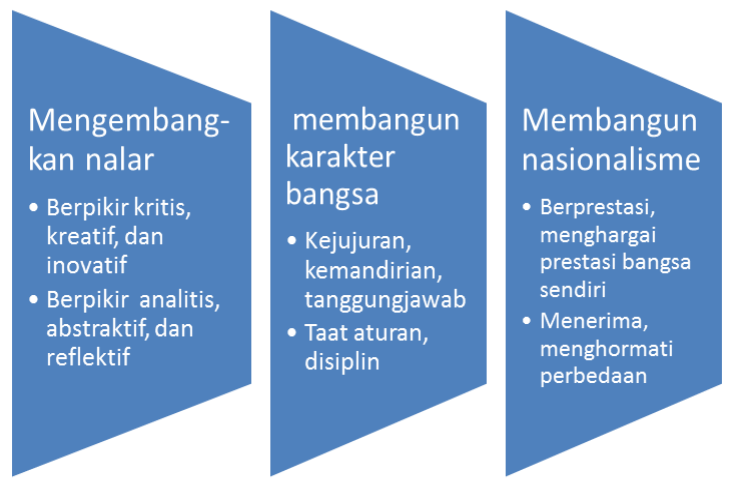

\section{Gambar 4 Mengembangkan Nalar, Membangun karakter, dan Membangun Nasionalisme}

Memahami hasil akhir dari pelaksanaan pengabdian masyarakat yang dilakukan oleh tim dari Fakultas Hukum Universitas Pembangunan Nasional "Veteran" Jakarta dapat di lihat dari jawaban atas pertanyaan yang sudah dipersiapkan sebelumnya oleh TIM Pengabdian masyarakat untuk peserta yang hadir dan mengikuti kegiatan sejak awal hingga akhir, pada Komplek Amanah dan Komplek Barokah RT 07 Bulak Perwira II Kelurahan Perwira Kecamatan Bekasi Utara, Kota Bekasi. Hasil sementara yang di dapat oleh tim pengabdian adalah keingintahuan masyarakat yang mendalam, tentang fenomena arus globalisasi baik yang terjadi secara international maupun pengaruh sudah terdampak pada wilayah nasional (Domestik).

Selain jawaban yang telah diterima, hasil dapat terlihat bahwa pemahaman ideologi negara dan dasar negara dapat dipahami ditengah kalangan masyarakat dengan terciptanya rasa toleransi yang muncul dalam kehidupan sehari-hari. Pada prinsipnya penyebaran ideologi Pancasila sebagai dasar negara dan ideology negara adalah hal yang dapat di jangkau oleh masyarakat, hanya saja, ketika sosialisasi dan penyebaran Pancasila dapat secara massif dilakukan oleh pemerintah.

Dalam menghadapi ancaman-ancaman terhadap ideologi yang sudah dimiliki negara Indonesia, Pemerintah harus mampu bersaing dengan kecepatan tekhnologi yang sudah massif terjadi beberapa tahun belakangan ini, jika tidak diatasi dengan strategi pemerintah yang cepat dan efektif maka tidak dapat menutup kemungkinan, ancaman terhadap ideologi negara dapat terjadi, Misal pemahaman ideologi negara lain atau paham ideologi lain selain Pancasila yang masuk melalui kecepatan tekhnologi dari berkembang pesatnya Sosial media. 
Warga Masyarakat sebagai subjek terakhir penerapan ideologi bangsa itu dapat dilaksanakan harus terjaga dari tindakan atau perilaku yang tidak sejalan dengan pancasila. penyebaran ideologi selain pancasila sangat mudah diterima dari arus tekhnologi yang semakin pesat, setiap orang memiliki akun sosial media yang lebih dari satu. Hal ini didasari oleh perembangan tekhnologi yang di bawa dari arus globalisasi

\section{KESIMPULAN}

Pelakasanaan program pengabdian masyarakat yang dilakukan di RT 07 Bulak Perwira II Kelurahan Perwira Kecamatan Bekasi Utara, pada prinsipnya adalah program yang sesuai dengan kebutuhan antara kedua belah pihak. Pihak Tim Pengabdi dapat berguna kepada masyarakat memberikan pemahaman urgensi implementasi nilai-nilai pancasila, di pihak lain permasalahan mitra sebagai warga negara yang tumbuh berkembang untuk mengahadapi arus globalisasi di era industri 4.0 membutuhkan pegetahuan yang mendalam, untuk bagaimana masyarakat tetap menjalankan kehidupan bermasyarakat namun tidak melupakan jati diri bangsanya yang hidup dengan penuh toleransi. Selain itu tetap melaksanakan dan melakukan perilaku yang pancasilais.

Dengan pelaksanaan sosialisasi materi dan tanya jawab kepada masyarakat setempat, tim pengabdi menjadi lebih memahami bahwa tolok ukur masyarakat hari ini masih banyak membutuhkan akan sosialisasi implemantasi nilai-niilai pancasila. Khususnya untuk warga masyarakat setempat kota bekasi sebagai daerah penopang ibu kota, perubahan sosial tidak dapat dihindarkan dari kota yang berangkat dari wilayah pedesaan, berubah menjadi kota yang sangat metropolis, hidup dengan tingkat hedonisme yang tinggi dan kurang akan menerapkan tindakan atau perilaku budaya ketimuran.

\section{DAFTAR PURSTAKA}

Chairiyah. (2014). Revitalisasi Nilai-Nilai Pancasila Sebagai Pendidikan Karakter. Trihayu: Jurnal Pendidikan Ke-SD-an, 1(1), 54-62.

Fahrudin, A. (2012). Pemberdayaan Partisispasi dan Penguatan Kapasitas Masyarakat. Bandung: Humaniora.

Hakim, M. A. (2016). Repositioning Pancasila Dalam Pergulatan Ideologi-Ideologi Gerakan Di Indonesia Pasca-Reformasi. Jurnal Kontemplasi, 04(01), 132-163.

Harefa, A. (2012). Pancasila sebagai Ideologi Dinamis. Didaktik: Jurnal Ilmiah Pendidikan, Humaniora, Sains, dan Pembelajarannya, 6(2), 879-891. 
Herdiana, D. (2018). Sosialisasi Kebijakan Publik: Pengertian dan Konsep Dasar. Jurnal Ilmiah Wawasan Insan Akademik, I(3), 13-26

Kristiono, N. (2017). Penguatan Ideologi Pancasila di Kalangan Mahasiswa Universitas Negeri Semarang. Jurnal Harmony, 2(2), 193-204.

Mardikanto, T. (2014). CSR (Corporate Social Responsibility) Tanggungjawab Sosial Korporasi. Bandung: Alfabeta.

MD, Mahfud. (2018). Kongres Pancasila UGM Mahfud MD Tegaskan Indonesia Bukan Negara Agama, diakeses dari https://edukasi.kompas.com/read/2018/08/24/21551201/kongres-pancasila-ugmmahfud-md-tegaskan-indonesia-bukan-negara-agama?page=all)

Rohmanu, A. (2013). Pluralisme, Demokrasi dan Keadilan Sosial dalam Konsepsi Fiqih Humanistik Abou El-Fadl. Jurnal Islamica, 4(1).

Sulistio, K., \& Ismail, Y. (2018). The Analysis of Bekasi Industrial Tourism's Brand Awareness. FIRM Journal of Management Studies, 3(2), 167-182.

Sururi, A. (2015). Pemberdayaan masyarakat melalui program pembangunan infrastruktur perdesaan dalam meningkatkan kesejahteraan masyarakat Kecamatan Wanasalam Kabupaten Lebak. Sawala: Jurnal Administrasi Negara, 3(2), 1-25. 